\title{
On the Determinants of Unemployment Rate in Nigeria: Evidence from Fully Modified OLS and Error Correction Model
}

\author{
${ }^{1}$ Adenomon, M. O.; ${ }^{1}$ Okoro-Ugochukwu, N. A.; ${ }^{2}$ Adenomon, C. A. \\ 1. Department of Statistics, Nasarawa State University, Keffi, Nasarawa State. \\ 2. Department of Administration, Federal Medical Centre, Bida, Niger State \\ adenomonmo@nsuk.edu.ng; +2347036990145
}

\begin{abstract}
This study employed the Fully Modified Ordinary Least Squares (FMOLS) and the Error Correction Model (ECM) to investigate the long-run and short-run determinants of unemployment rate in Nigeria. To achieve this annual data on unemployment rate, inflation rate, interest rate, exchange rate and population growth from 1981 to 2016 was collected from Central Bank Statistical Bulletins and the World Bank website. The ADF test revealed that the macroeconomic variables are stationary at first difference while the Cointegration test revealed that the variables are cointegrated. Using unemployment rate as dependent variable, the FMOLS model revealed that exchange rate and population growth are positively significantly related to unemployment rate, interest rate and inflation rate were negatively related to unemployment rate but only interest rate was significant. The short run relationship revealed that the coefficient of the ecm(-1) is negative and statistically significant at 5\% level indicating that the system corrects its previous period disequilibrium at the speed of $48.93 \%$ yearly. This study concludes that high exchange rate and population growth can lead to increase in unemployment rate in Nigeria while the government should develop the industrial sector and non-oil sector in order to generate employment and boost export in Nigeria.
\end{abstract}

Keywords: Determinants, Unemployment Rate, OLS, FMOLS, ECM.

\subsection{Introduction}

Unemployment rate can be seen as a measure of the occurrence or frequency of unemployment and which is usually calculated as a percentage simply by dividing the number of unemployed individuals by all individuals currently in the labour force. During periods of recession, an economy usually experiences a relatively high unemployment rate. The National Bureau of Statistics of Nigeria stated that Nigerian youths are among the most important resources the country need is to be able to achieve prosperity and progress (Maigwa and Kipesha, 2013). In addition, the population of every economy constitutes of two categories, the economically active and the economically inactive (Muhdin, 2016). 
In general, unemployment among young people has become the main challenge which all the nations in the world are facing presently. The resultant effects of unemployment are extensive crises in psychological, social and economic perspectives, some of them are: increasing crime rates and violence in the society, reliance on family, low self-confidence by the victim, poor social adaptation, unhappiness and loss of confidence (Kabaklarli \& Bulus, 2011). Nasir et al (2009) in the same manner showed that unemployment affects the socio-economic status of the family, and also leads to poor emotional health, dependency and surges up the magnitude of corruption, prostitution, drug addiction, kidnapping, ritual killings, suicide and other crimes in a society.

This study examined the determinants of unemployment rate in Nigeria using Fully Modified Ordinary Least Squares (FMOLS) and Error Correction Model (ECM).

\subsection{Empirical Literature Review}

First we defined the following:

Unemployment is defined by the Bureau of Labour Statistics as people who do not have a job, have actively looked for work in the past four weeks, and are currently available for work. There are three major types of unemployment - Structural Unemployment, Critical Unemployment and Frictional unemployment.

Inflation is a sustained increase in the general price level of goods and services in an economy over a period of time. When the price level rises, each unit of currency buys fewer goods and services. Consequently, inflation reflects a reduction in the purchasing power per unit of money - a loss of real value in the medium of exchange and unit of account within the economy.

Exchange rate is the rate of transformation of one currency to another. Nzotta (2004) defines exchange rates as the price of one currency in terms of another.

Previous literatures are available on the subject matter, highlighting various causes and consequences regarding increasing rate of unemployment using statistical methods.

Pallis (2006) focused his study on the relationship between inflation and unemployment in new European Union member states. He obtained the data used in the analysis the annual data that covered the period from 1994 to 2005, which was taken from European commission 2004 referred to the new ten (10) European Union (EU) member states. The three variables used are "the price deflator of GDP at market prices, the nominal compensation per employee and then 
the total employment rate (\%). In estimating the variables used in the study, Nonlinear least square method of estimations and E-views techniques were used. The findings proved and concluded that the application of common policies across economy may be questionable because of the different effects of these policies on unemployment and inflation.

Ozturk \& Akhtar (2009) studied and analysed a comprehensive approach to unemployment by using VAR of "Variance Decomposition and Impulse response function analysis". They were intereste $d$ in studying interrelationship among Foreign Direct investment (FDI), Export, Gross Domestic product (GDP) and unemployment in Turkey for the period of 2000 to 2007. They found only two counteracting vectors in the system, showing long run relationship. They now concluded that foreign direct investment (FDI) did not lead to reduce unemployment in Turkey. GDP is positively affected by variations in exports but is also insignificant. So they did not found any evidence of export led growth in Turkey. Again, Variations in GDP was not attached with reduction of unemployment.

Eita \& Johnson (2010) studied the causes of unemployment in Namibia for the period 1971 to 2007. The results revealed that in Namibia, there exit a negative relationship between unemployment and inflation. It is noted that if wages increases, Unemployment responds positively if actual output is below potential output. An increase in investment results to decrease in unemployment significantly. The results provide evidence that the Phillips curve holds for Namibia and unemployment can be reduced or decreased by increasing aggregate demand.

El-Agrody et al. (2010) examined and evaluates the economic study of unemployment and its impact on the GDP for Egypt. Data was collected from year 1994 to 2004 in Egypt. Simple and multiple linear regression analysis were applied. Variables used in the study were privatization, population, consumption expenditure, interest rates, exchange rates, technology, agricultural domestic product, real wage rates and agricultural investment. The results and the findings showed that there is a significant positive impact of national unemployment, national investment, exchange rate and average per capita share of GDP on the volume of GDP. The results in addition also highlighted privatization and increasing population as the main reasons of increasing unemployment. They in tum recommended that privatization policies need to be revised and to reduce interest rates in order to lowering the agricultural unemployment.

Afzal \& Awais (2012) investigates and analyzes the relationship between InflationUnemployment Trade Off: Evidence taken from Pakistan. Using the method of ordinary least squares 
(OLS) and also equation by the method of non-linear least squares (NLS). The Data on consumer price index and unemployment were collected from Government of Pakistan (GOP), economic survey (various issues) for the period $1973-2010$. Then, the empirical results obtained for the first three periods (1974-2010, 1974-82, and 1974-92) and then the last period 2000-2010 show that the Phillips curve holds in Pakistan because the unemployment coefficient is negative and also very significant. For other periods (1981-2000 and 1981-2010) though there is negative relationship between inflation and unemployment, the unemployment coefficients are not very significant.

Aminu \& Anono (2012) studied the relationship between unemployment and inflation in the Nigerian economy. Data was used from 1977 and 2009 and was analyzed with the application of Augmented Dickey-Fuller techniques in order to examine the unit root property of the series, however, Granger causality test was conducted to determine if there is causality between unemployment and inflation, in addition cointegration test was conducted through the application of Johansen cointegration technique to examine the long-run relationship between the two phenomenon, they later used $\mathrm{ARCH}$ and $\mathrm{GARCH}$ technique to conduct and examine if there is existence of volatility in the series. The results of the analysis indicated that inflation impacted negatively on unemployment. The causality test however revealed that there is no causality between unemployment and inflation in Nigeria during the specified period of study but it is noted that a long-run relationship exists between them as confirmed by the cointegration test. The result of $\mathrm{ARCH}$ and GARCH test then revealed that the time series data for the period under review exhibits a high volatility clustering.

Maqbool et.al. (2013) upon examining the empirical relationship among the unemployment, population, foreign direct investment, gross domestic product, inflation, and external debt in Pakistan. The use of Autoregressive Distributed Lag (ARDL) approach was applied to test determinants of unemployment. The results however revealed that both gross domestic product, population, foreign direct investment and inflation are significant determinants of unemployment in Pakistan in both shortrun and long-run.

Baah- Boateng (2013) studied the determinants of Unemployment rate in Ghana for a period of 1991 to 2005 using binary Regression Estimate to analyse its data. A cross-sectional estimation of a probit regression model also shows that there is a strong effect of demand factors on unemployment, and this also shows a weak employment generating impact of economic growth. 
Empirical analysis which was employed also confirms very high vulnerability of youth and urban dwellers to unemployment whereby education and gender explained unemployment in some instances. Reservation wage is also observed to have an increasing effect of unemployment.

Kemi \& Ayo (2014) investigates the issue of Unemployment and Economic Growth in Nigeria. The study actually validated Okun's law in Nigeria. In order to examine the relationship between unemployment rate and economic growth, Error Correction Model (ECM) and Johasen cointegration test were employed to determine both the short-run and long-run relationships among the macro variables employed in the study. The Empirical findings however revealed that there exist both the short and the long run relationship between unemployment rate and output in Nigeria.

Cheema \& Atta (2014) analyses Economic Determinants of Unemployment in Pakistan: Co-integration Analysis. This study reveals the determinants of unemployment by applying the Auto Regressive Distribution Lag Model (ARDL) bound approach using the time series data from the period of 1973 to 2010. The outcomes indicate that unemployment has statistically significant and positive relationships with output gap, Productivity and Economic Uncertainty while it has statistically significant but negative relationships with Gross Fixed Investment and Openness of Trade.

Muhdin (2016) studied the main issues underlying unemployment in Ethopia. The data used was collected from Central Statistical Agency (CSA) in 2015 and a total of 16984 were considered for the analysis. The use of descriptive statistic like percentages, mean value and cross tabulation in the study shows that youth unemployment is highly related with regional location, sex, marital status and education. Using descriptive and cross tabulation analysis, the study shows that youth unemployment is highly related with regional location, sex, marital status and education. Out of the total responses obtained in the survey, 53.5 percent are female. The average year of the sample under review was 23.3 years. Moderately, larger proportion, 59.9 percent, of the youth were never married, however about 33.9 percent of them were married, 0.9 percent of live together and the remaining 5.3 percent were noticed to be divorced, separated and widowed. Also, on the average, household size is seen to be 2.2 family members. The survey shows that the literacy level is very high for Ethiopian Youths. 


\subsection{Model Specification}

\section{Fully Modified OLS}

The FMOLS is an optimal single-equation method based on the use of OLS with semiparametric correction for serial correlation and endogeneity (Phillips \& Loretan, 1991).

Suppose $\mathrm{y}_{\mathrm{t}}$ be an $\mathrm{n}$-vector $\mathrm{I}(1)$ process and $\mathrm{u}_{\mathrm{t}}$ be an $\mathrm{n}$-vector stationary time series. The partition of these vectors can be seen as

$$
y_{t}=\left[\begin{array}{l}
y_{1 t} \\
y_{2 t}
\end{array}\right]_{m}^{1}, \quad u_{t}=\left[\begin{array}{l}
u_{1 t} \\
u_{2 t}
\end{array}\right]_{m}^{1}, \quad n=m+1
$$

Assuming that the generating mechanism for $y_{t}$ is the cointegrated system given as

$$
\begin{aligned}
& y_{1 t}=\beta^{\prime} y_{2 t}+u_{1 t} \\
& \Delta y_{2 t}=u_{2 t}
\end{aligned}
$$

The basic idea in this procedure is to modified the OLS estimator

$$
\beta^{*}=\left(Y_{2}^{\prime} Y_{2}\right)^{-1} Y_{2}^{\prime} y_{1}
$$

(4) (Phillips \& Loretan, 1991).

But $\sigma_{21}=\sum_{k=0}^{\infty} E\left(u_{20} u_{1 k}\right)$. If $\hat{\sigma}_{21}$ is consistent estimator of $\sigma_{21}$, then we have a modified OLS estimator

$$
\beta * *=\left(Y_{2}^{\prime} Y_{2}\right)^{-1}\left(Y_{2}^{\prime} y_{1}^{+}-T \hat{\sigma}_{21}\right)
$$

Then the Fully Modified OLS (FMOLS) estimator employs both the serial correction and endogeneity corrections and is given as

$$
\begin{aligned}
& \beta^{+}=\left(Y_{2}^{\prime} Y_{2}\right)^{-1}\left(Y_{2}^{\prime} y_{1}^{+}-T \hat{\delta}^{+}\right) \\
& \text {where } \\
& y_{1 t}^{+}=y_{1 t}-\hat{\sigma}_{21}^{\prime} \hat{\Sigma}_{22}^{-1} \Delta y_{2 t} \\
& \hat{\delta}^{+}=\hat{\Delta}\left[\begin{array}{l}
1 \\
-\Sigma_{22}^{-1} \hat{\sigma}_{21}
\end{array}\right]
\end{aligned}
$$

where $\hat{\Delta}$ is a consistent estimate of $\Delta=\sum_{k=0}^{\infty} E\left(u_{20} u_{1 k}\right)$ and $\hat{\Sigma}$ is consistent for $\Sigma$

Fully modified test statistics that are based on $\beta^{+}$may be constructed in the usual way. Thus, for t-ratios we defined as 


$$
\begin{aligned}
& t_{i}^{+}=\left(\beta_{i}^{+}-\beta_{i}\right) / s_{i}^{+} \\
& \text {where }\left(s_{i}^{+}\right)^{2}=\hat{\sigma}_{11.2}\left[\left[Y_{2}^{\prime} Y_{2}\right]^{-1}\right]_{i i} \\
& \text { here } \hat{\sigma}_{11.2}=\hat{\sigma}_{11}-\hat{\sigma}_{21}^{\prime} \hat{\Sigma}_{22}^{-1} \hat{\sigma}_{21}
\end{aligned}
$$

And is based on components of $\hat{\Sigma}$ which is again an estimate of the long-run covariance matrix $\Sigma$ (Phillips \& Hansen (1990); Phillips \& Loretan (1991)). Application of this method can be found in Kuhe (2016) and Adenomon et al. (2018).

\section{Augmented Dickey-Fuller (ADF) Unit Root test}

Engle and Granger, (1987) considered seven test statistics in a simulation study to test cointegration. Engle and Granger concluded that the Augmented Dickey Fuller test was recommended and can be used as a rough guide in applied work

To distinguish a unit root, we can run the regression

$$
\Delta Y_{t}=b_{o}+\sum_{j=1}^{k} b_{j} \Delta Y_{t-j}+\beta t+\gamma Y_{t-1}+u_{t}
$$

The model in (1) may be run without $t$ if a time trend is not necessary. This technique was applied in Ajayi and Mougoue (1996). If there is unit root, differencing Y should result in a white-noise series (no correlation with $\mathrm{Y}_{\mathrm{t}-1}$ ).

The Augmented Dickey-Fuller (ADF) test of the null hypothesis of no unit root test is of the form $\mathrm{H}_{\mathrm{o}}: \beta=\gamma=0$ (if there is trend we use F-test) and $\mathrm{H}_{\mathrm{o}}: \gamma=0$ (if there is no trend we use t-test). If the null hypothesis is accepted, we assume that there is a unit root and difference the data before running a regression. If the null hypothesis is rejected, the data are stationary and can be used without differencing (Salvatore \& Reagle, 2002).

\section{Johansen and Juselius Cointegration Test}

The most popular test for cointegration testing is the Johansen and Juselius cointegration test (i.e Maximum Eigenvalue test and the trace test) (Johansen \& Juselius, 1990). The maximum eigenvalue test and the trace test are used as procedures to determine the number of cointegration vectors.

The maximum eigenvalue statistic test the null hypothesis of $r$ cointegrating relations against the alternative of $r+1$ cointegrating relations for $r=0,1,2, \ldots, n-1$. This test statistic is computed as

$$
\lambda_{\text {max }}(r, r+1)=-T \ln \left(1-\hat{\lambda}_{r+1}\right)
$$


where $\hat{\lambda}$ is the computed maximum eigenvalues and $\mathrm{T}$ is the sample size.

The main difference between the maximum eigenvalue test and the trace test is that the trace test is a joint test, whereas the maximum eigen value test conducts separate test on the individual eigenvalues.

Trace statistic examines the null hypothesis of $\mathrm{r}$ cointegrating relations against the alternative of $n$ cointegrating relations, where $n$ is the number of variable in the system for $\mathrm{r}=0,1,2, \ldots, \mathrm{n}-1$.

It is computed according to the following formula $\lambda_{\text {trace }}(r)=-T \sum_{i=r+1}^{n} \ln \left(1-\hat{\lambda}_{i}\right)$

The results of trace test should be chosen where trace and maximum eigenvalue statistic may yield different results in some case (Habte, 2014).

\section{The Error Correction Model}

The cointegrating regression considers only the long-run property of a given model, and does not deal with the short-run dynamics explicitly. Clearly, a good time series modelling should describe both short-run dynamics and the long-run equilibrium simultaneously. For this purpose error correction model (ECM) was developed. Although ECM has been popularized after Engle and Granger, it has a long tradition in time series econometrics dating back to Sargan (1964) as documented by Hendry (2003). To start, we define the error correction term by

$$
\varepsilon_{t}=y_{t}-\beta x_{t}
$$

Where $\beta$ is a cointegration. In fact $\varepsilon_{t}$ is the error from a regression of $y_{t}$ on $x_{t}$. Then an ECM is simply defined as

$$
\Delta y_{t}=\alpha \varepsilon_{t-1}+\gamma \Delta x_{t}+u_{t}
$$

where $u_{t}$ is iid. the ECM equation simply says that $\Delta y_{t}$ can be explained by the $\varepsilon_{t-1}$ and $\Delta x_{t}$. We can notice that $\varepsilon_{t-1}$ can be thought of as an equilibrium error (or disequilibrium term) occurred in the previous period (Salmon, 1982).

\subsection{Materials and Methods}

The data used for this analysis is a secondary data. The data was collected from Central Bank of Nigeria Statistical bulletin from 1981 to 2016 and World Bank web site (www.worldbank.org). 
the data sets was transform using natural log to ensure normality, stability and to reduce skewness and kurtosis.

\subsection{Data Analysis and Discussion of Results}

The statistical analysis was carried using EViews 7.2 statistical software. The data used in this analysis are presented in Table 1 presented at the appendix. While the natural logarithm transform of the economics variables are presented in Table 2 presented at the appendix. The data used in this work can be graphically represented as in Fig. 2 below

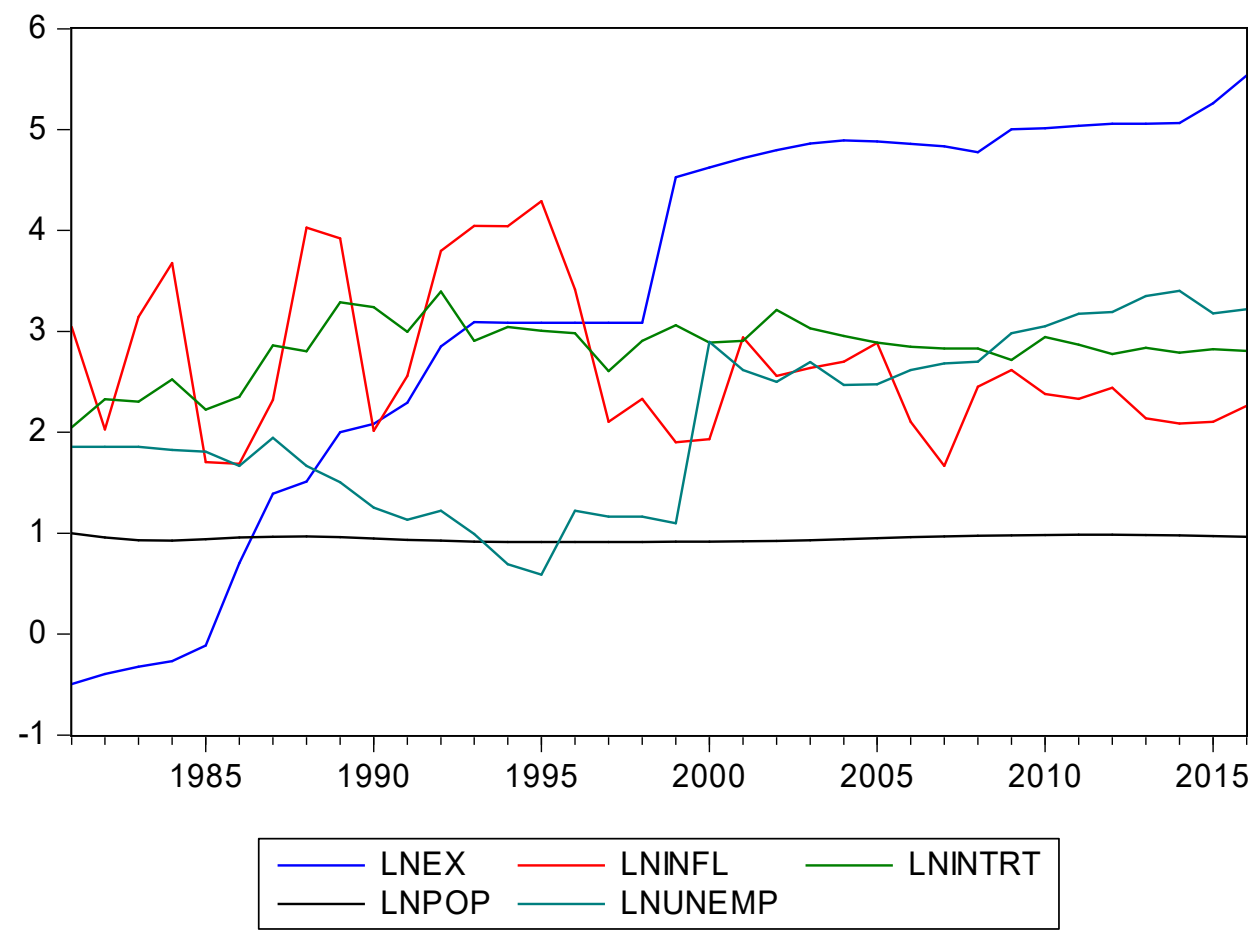

Fig 2: A Graph of some Macroeconomic variables in Nigeria from 1981 to 2016.

In fig 2 above, It is observed that Exchange Rate exhibit a positive growth; Under Inflation rate, there is fluctuation; Observe that Population Growth is stable, Interest rate and Unemployment also fluctuates.

Table 3: Descriptive statistics of the dependent and independent variables.

\begin{tabular}{|l|c|c|c|c|c|}
\hline & LNEX & LNINFL & LNINTRT & LNPOP & LNUNEMP \\
\hline Mean & 3.293656 & 2.674964 & 2.828446 & 0.947595 & 2.103168 \\
\hline Median & 3.811330 & 2.446680 & 2.864765 & 0.948614 & 1.901105 \\
\hline Maximum & 5.535320 & 4.289090 & 3.394510 & 0.998815 & 3.401200 \\
\hline Minimum & -0.494300 & 1.667710 & 2.047690 & 0.911553 & 0.587790 \\
\hline Std. Dev. & 1.947536 & 0.762144 & 0.293679 & 0.026654 & 0.843132 \\
\hline
\end{tabular}




\begin{tabular}{|l|c|c|c|c|c|}
\hline Skewness & -0.735632 & 0.737983 & -0.757065 & 0.098451 & -0.065551 \\
\hline Kurtosis & 2.202316 & 2.358079 & 3.611314 & 1.669811 & 1.707701 \\
\hline & & & & & \\
\hline Jarque-Bera & 4.201373 & 3.885804 & 3.999444 & 2.712260 & 2.530838 \\
\hline Probability & 0.122372 & 0.143288 & 0.135373 & 0.257656 & 0.282121 \\
\hline & & & & & \\
\hline Sum & 118.5716 & 96.29872 & 101.8240 & 34.11341 & 75.71405 \\
\hline Sum Sq. Dev. & 132.7513 & 20.33022 & 3.018649 & 0.024865 & 24.88051 \\
\hline & & & & & 36 \\
\hline Observations & 36 & 36 & 36 & 36 & 36 \\
\hline
\end{tabular}

Where: LNEX= Log of Exchange Rate; LNINFL= Log of Inflation rate; LNINTRT $=$ Log of Interest Rate; LNPOP = Log of Population Growth; LNUNEMP= Log of Unemployment In table 1 above, the mean values for log of Exchange Rate, Log of Inflation rate, Log of Interest Rate, Log of Population Growth and Log of Unemployment are 3.293656, 2.674964, 2.828446, 0.947595 and 2.103168 respectively. Jarque-Bera test revealed that the variables are normally distributed (since all P-values $=0.1223,0.1433,0.1354,0.2577,0.2821>0.05$ ) which means that we accept $\mathrm{H}_{0}$ and conclude that all the variables are Normally Distributed and the implication of this is that we can use the proposed Model that is Fully Modified Ordinary Least Square and Error Correction models.

\section{Table 4: Unit Root Test}

The unit root test for all the variables can be represented in the tabular form shown below:

\begin{tabular}{|l|l|l|l|l|}
\hline VARIABLES & ADF & P-values & ORDER & REMARK \\
\hline D(LNEX) & -5.020825 & 0.0002 & I (1) & Stationary \\
\hline D(LNINFL) & -7.240855 & 0,0000 & I (1) & Stationary \\
\hline D(LNINTRT) & -8.707736 & 0.0000 & I (1) & Stationary \\
\hline D(LNPOP) & -7.056791 & 0.0000 & I (1) & Stationary \\
\hline D(LNUNEMP) & -6.641959 & 0.0000 & I (1) & Stationary \\
\hline
\end{tabular}

The table 4 above all the variables are of order 1 that is all the variables are stationary at first difference. Details are in table in the appendix. 


\section{Table 5: Cointegration test}

Date: 05/18/18 Time: 01:58

Sample (adjusted): 19832016

Included observations: 34 after adjustments

Trend assumption: Linear deterministic trend

Series: LNEX LNINFL LNINTRT LNPOP LNUNEMP

Lags interval (in first differences): 1 to 1

Unrestricted Cointegration Rank Test (Trace)

\begin{tabular}{ccccc}
\hline \hline $\begin{array}{c}\text { Hypothesized } \\
\text { No. of CE(s) }\end{array}$ & Eigenvalue & $\begin{array}{c}\text { Trace } \\
\text { Statistic }\end{array}$ & $\begin{array}{c}0.05 \\
\text { Critical Value }\end{array}$ & Prob. $^{* *}$ \\
\hline \hline None * & 0.851668 & 139.1505 & 69.81889 & 0.0000 \\
At most $1{ }^{*}$ & 0.744829 & 74.26825 & 47.85613 & 0.0000 \\
At most 2 & 0.409899 & 27.83033 & 29.79707 & 0.0829 \\
At most 3 & 0.165586 & 9.896657 & 15.49471 & 0.2888 \\
At most 4 & 0.104213 & 3.741798 & 3.841466 & 0.0531 \\
\hline \hline
\end{tabular}

Trace test indicates 2 cointegrating eqn(s) at the 0.05 level

$*$ denotes rejection of the hypothesis at the 0.05 level

Unrestricted Cointegration Rank Test (Maximum Eigenvalue)

\begin{tabular}{ccccc}
\hline \hline $\begin{array}{c}\text { Hypothesized } \\
\text { No. of CE(s) }\end{array}$ & Eigenvalue & $\begin{array}{c}\text { Max-Eigen } \\
\text { Statistic }\end{array}$ & $\begin{array}{c}0.05 \\
\text { Critical Value }\end{array}$ & Prob. $^{* *}$ \\
\hline \hline None ${ }^{*}$ & 0.851668 & 64.88226 & 33.87687 & 0.0000 \\
At most $1{ }^{*}$ & 0.744829 & 46.43792 & 27.58434 & 0.0001 \\
At most 2 & 0.409899 & 17.93368 & 21.13162 & 0.1323 \\
At most 3 & 0.165586 & 6.154859 & 14.26460 & 0.5934 \\
At most 4 & 0.104213 & 3.741798 & 3.841466 & 0.0531 \\
\hline \hline
\end{tabular}

Max-eigenvalue test indicates 2 cointegrating eqn(s) at the 0.05 level

* denotes rejection of the hypothesis at the 0.05 level

**MacKinnon-Haug-Michelis (1999) p-values

Since P-value $=0.0829>0.05$ which appeared under Atmost 2, we therefore state that the Trace Test indicates 2 cointegration eqn(s) at 0.05 level which implies that the variables are cointegrated that is there exist a long run relationship among the macro variables.

Furthermore the maximum eigen Test also indicated 2 cointegration eqn(s) at the 0.05 level depict the long run relationship among the Unemployment rate and all other independent variables.

\section{Table 6: Fully Modified Ordinary Least Squares (FMOLS)}

Dependent Variable: LNUNEMP

Method: Fully Modified Least Squares (FMOLS)

Date: 05/18/18 Time: 01:59

Sample (adjusted): 19822016 
Included observations: 35 after adjustments

Cointegrating equation deterministics: $\mathrm{C}$

Long-run covariance estimate (Bartlett kernel, Newey-West fixed bandwidth $=4.0000$ )

\begin{tabular}{crrrr}
\hline \hline Variable & Coefficient & Std. Error & t-Statistic & Prob. \\
\hline \hline LNEX & 0.316484 & 0.067104 & 4.716341 & 0.0001 \\
LNINFL & -0.159174 & 0.147440 & -1.079581 & 0.2889 \\
LNINTRT & -1.277057 & 0.480040 & -2.660314 & 0.0124 \\
LNPOP & 14.49323 & 4.114303 & 3.522646 & 0.0014 \\
C & -8.590843 & 4.343328 & -1.977940 & 0.0572 \\
\hline \hline R-squared & 0.744479 & Mean dependent var & 2.110221 \\
Adjusted R-squared & 0.710410 & S.D. dependent var & 0.854363 \\
S.E. of regression & 0.459763 & Sum squared resid & 6.341468 \\
Durbin-Watson stat & 1.191382 & Long-run variance & 0.296870 \\
\hline \hline
\end{tabular}

Since there exist long run relationship among the variables, then the Fully modified ordinary least square model becomes appropriate to be used to obtain the long run estimates. Then the FMOLS obtained in Table 6 and the estimated model is given below:

LNUEMP $=-8.5908+0.3165$ LNEX -0.1592 LNINFL -1.2771 LNINTRT +14.4932 LNPOP $+\varepsilon_{t}$

The model above reveal that Unemployment becomes negative if there is no influence of all other variables. The model also show that Exchange rate and population growth are positively related to unemployment rate which implies that every unit increase in exchange rate and population growth will result to an increase in unemployment rate. While inflation rate and interest rate are negatively related to unemployment rate which implies that every unit increase in Inflation rate and Interest rate will result to a decrease on Unemployment rate. The model further revealed that Exchange rate, interest rate and population growth are all significant since all the P-values are less than 0.05 level of significance, only inflation rate is not significant since the P-value is greater than 0.05 level of significance.

\section{Table 7: Cointegration Test - Hansen Parameter Instability (FM-OLS)}

Cointegration Test - Hansen Parameter Instability

Date: 05/18/18 Time: 02:00

Equation: UNTITLED

Series: LNUNEMP LNEX LNINFL LNINTRT LNPOP

Null hypothesis: Series are cointegrated Cointegrating equation deterministics: $\mathrm{C}$

\begin{tabular}{ccccc}
\hline \hline & Stochastic & Deterministic & Excluded & \\
Lc statistic & Trends (m) & Trends (k) & Trends (p2) & Prob.* \\
\hline
\end{tabular}



0.288646
4
0
0
$>0.2$

*Hansen (1992b) $\mathrm{Lc}(\mathrm{m} 2=4, \mathrm{k}=0) \mathrm{p}$-values, where $\mathrm{m} 2=\mathrm{m}-\mathrm{p} 2$ is the number of stochastic trends in the asymptotic distribution.

The cointegration test in Table 5 shows that the $\mathrm{P}$-value $=0.2>0.05$ we accept the Null

Hypothesis and conclude that Variables are cointegrated.

Table 8: (Multicollinearity Test) Variance Inflation Factor (VIF)

Variance Inflation Factors

Date: 05/18/18 Time: 02:01

Sample: 19812016

Included observations: 35

\begin{tabular}{cccc}
\hline \hline Variable & $\begin{array}{c}\text { Coefficient } \\
\text { Variance }\end{array}$ & $\begin{array}{c}\text { Uncentered } \\
\text { VIF }\end{array}$ & $\begin{array}{c}\text { Centered } \\
\text { VIF }\end{array}$ \\
\hline \hline LNEX & 0.004503 & 7.933429 & 1.789701 \\
LNINFL & 0.021739 & 19.67270 & 1.478417 \\
LNINTRT & 0.230438 & 222.6443 & 1.856462 \\
LNPOP & 16.92749 & 1787.737 & 1.263904 \\
C & 18.86449 & 2224.059 & NA \\
\hline \hline
\end{tabular}

From the table 8 above, it can be seen that the Centered VIF for all the variables are less 10 (i.e VIF $<10$ ), this means that there is no presence of Multicollinearity among the variables in the FMOLS model estimated.

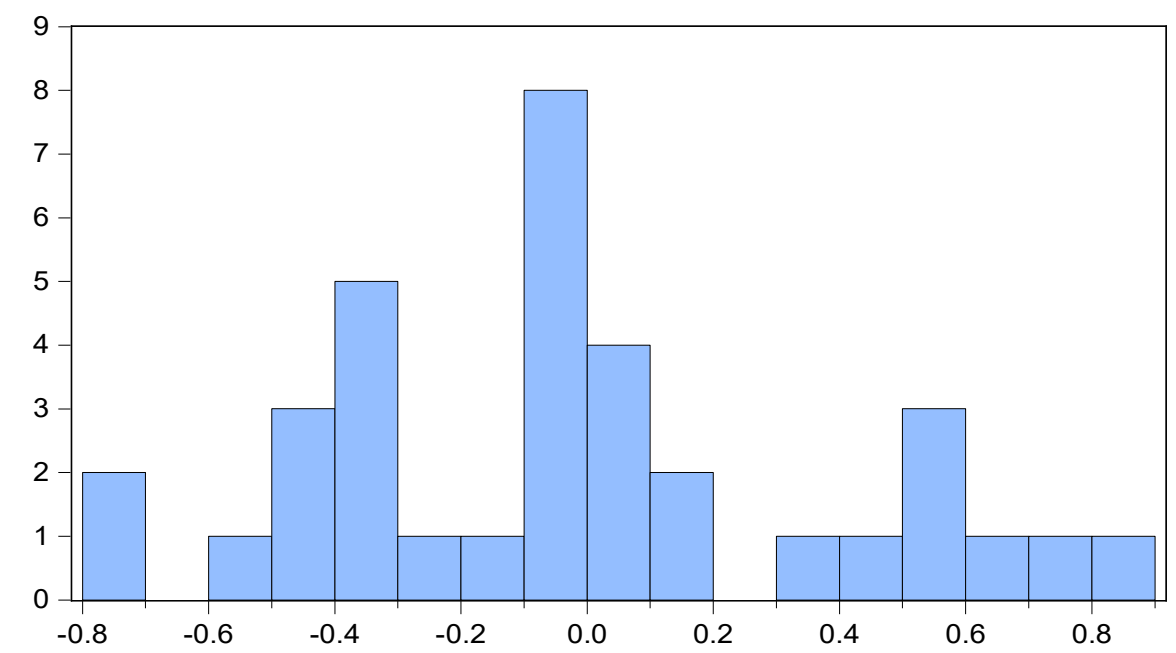

\begin{tabular}{|lr|}
\hline \multicolumn{2}{|l|}{ Series: Residuals } \\
Sample 1982 & 2016 \\
Observations & 35 \\
Mean & -0.023396 \\
Median & -0.034683 \\
Maximum & 0.862468 \\
Minimum & -0.789610 \\
Std. Dev. & 0.410345 \\
Skewness & 0.324144 \\
Kurtosis & 2.581071 \\
& \\
Jarque-Bera & 0.868846 \\
Probability & 0.647638 \\
\hline
\end{tabular}

Fig 3A: Normality Test 
The fig $3 \mathrm{~A}$ above revealed depict that the error term are normally distributed since the P-value 0.647 is greater than 0.05 level of significance. This implies that the estimated FMOLS Model is robust. The above Graphical representation in Fig 3A connotes a normal distribution.

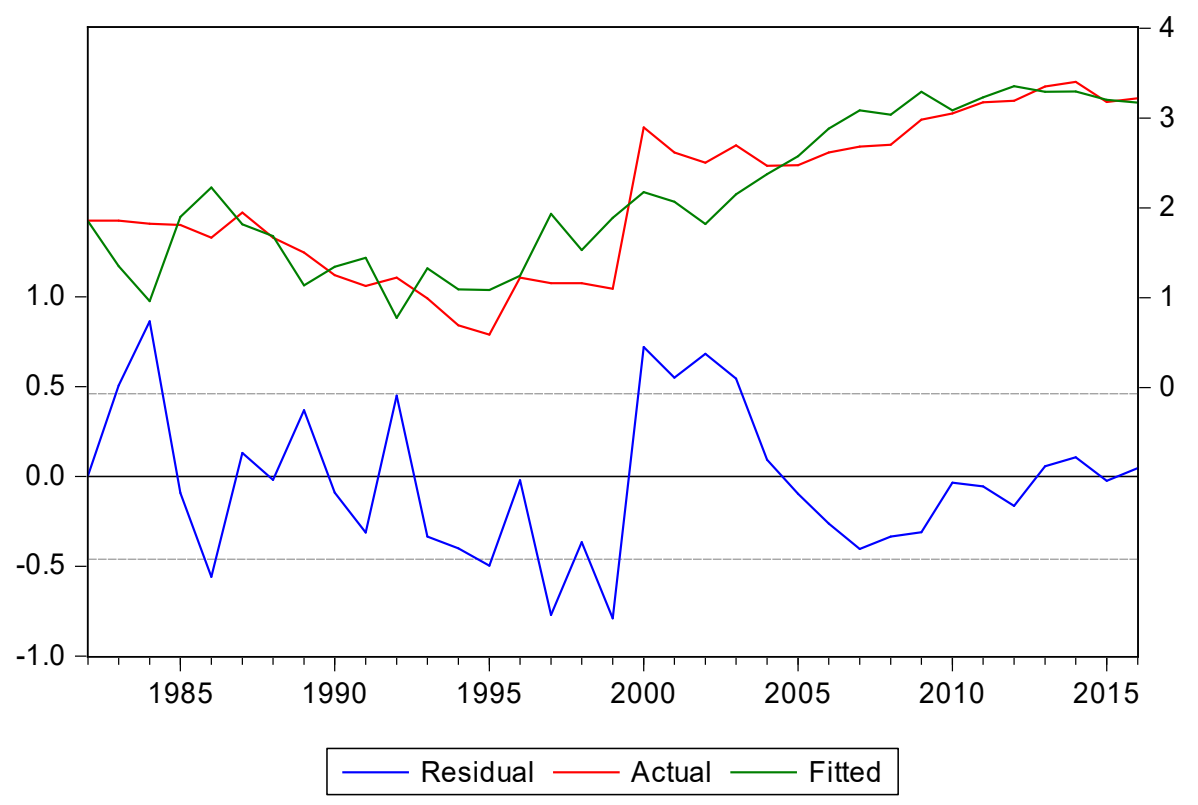

Fig. 3B: Graph of the Residual, Actual and Fitted Observation

The fig 3B graph above illustrates that the Actual and the Fitted are almost close to each other, which implies that the FMOLS model is robust.

To estimate the short run model using the ECM, the first stage is to obtain the optimum lag for the model as shown in table 9A below.

Table 9A: VAR Lag Order Selection Criteria

VAR Lag Order Selection Criteria

Endogenous variables: LNEX LNINFL LNINTRT LNPOP

LNUNEMP

Sample: 19812016

Included observations: 33

\begin{tabular}{ccccccc}
\hline \hline Lag & LogL & LR & FPE & AIC & SC & HQ \\
\hline \hline 0 & -30.14700 & NA & $5.79 \mathrm{e}-06$ & 2.130121 & 2.356865 & 2.206413 \\
1 & 103.3089 & 218.3823 & $8.26 \mathrm{e}-09$ & -4.442962 & -3.082500 & -3.985208 \\
2 & 166.7150 & 84.54150 & $9.01 \mathrm{e}-10$ & -6.770605 & -4.276426 & -5.931390 \\
3 & 227.3021 & $62.42307^{*}$ & $1.42 \mathrm{e}-10^{*}$ & $-8.927399^{*}$ & $-5.299502^{*}$ & $-7.706722^{*}$ \\
\hline \hline
\end{tabular}

* indicates lag order selected by the criterion

LR: sequential modified LR test statistic (each test at 5\% level)

FPE: Final prediction error

AIC: Akaike information criterion 
SC: Schwarz information criterion

HQ: Hannan-Quinn information criterion

In table 9A above, the VAR Lag selection Criteria indicated Optimal Lag as 3. Since we are using ECM Model, this then implies that the appropriate Lag selection becomes 2 .

\section{Table 9B: ECM for Short Run Analysis}

Dependent Variable: D(LNUNEMP)

Method: Least Squares

Date: 05/18/18 Time: 01:53

Sample (adjusted): $1984-2016$

Included observations: 33 after adjustments

\begin{tabular}{lrlrl}
\hline \hline Variable & Coefficient & Std. Error & t-Statistic & Prob. \\
\hline \hline C & 0.012732 & 0.065087 & 0.195614 & 0.8468 \\
D(LNUNEMP(-1)) & 0.337993 & 0.191764 & 1.762543 & 0.0925 \\
D(LNUNEMP(-2)) & 0.123905 & 0.160549 & 0.771759 & 0.4489 \\
D(LNEX(-1)) & 0.463811 & 0.209843 & 2.210273 & 0.0383 \\
D(LNEX(-2)) & -0.614194 & 0.219781 & -2.794575 & 0.0109 \\
D(LNINFL(-1)) & 0.041415 & 0.072109 & 0.574340 & 0.5718 \\
D(LNINFL(-2)) & -0.009572 & 0.068833 & -0.139064 & 0.8907 \\
D(LNINTRT(-1)) & 0.414488 & 0.366296 & 1.131565 & 0.2706 \\
D(LNINTRT(-2)) & 0.585830 & 0.310725 & 1.885365 & 0.0733 \\
D(LNPOP(-1)) & 17.28117 & 11.88619 & 1.453887 & 0.1608 \\
D(LNPOP(-2)) & -13.30747 & 9.500538 & -1.400707 & 0.1759 \\
$\quad-0.489328$ & 0.194418 & -2.516882 & 0.0200 \\
\hline ECM(-1) & 0.633658 & Mean dependent var & 0.041290 \\
R-squared & 0.441765 & S.D. dependent var & 0.371303 \\
Adjusted R-squared & 0.277420 & Akaike info criterion & 0.548718 \\
S.E. of regression & 1.616197 & Schwarz criterion & 1.092903 \\
Sum squared resid & 2.946151 & Hannan-Quinn criter. & 0.731820 \\
Log likelihood & 3.302137 & Durbin-Watson stat & 1.929024 \\
F-statistic & 0.008996 & & \\
Prob(F-statistic) & & & \\
\hline \hline
\end{tabular}

Table 9B above, contains the ECM Coefficients and its respective short run coefficients as well as their t-statistic and p-value. The ECM (-1) is the coefficient of the error correction mechanism and it has the correct sign and it is significant, which implies that the speed it takes for the system to come to its equilibrium point is about $48.9 \%$. The ECM model further revealed that there is significant short run effect of Exchange rate on unemployment rate in Nigeria.

\section{Table 10: Variance Inflation Factors (VIF)}

Variance Inflation Factors

Date: 05/18/18 Time: 02:05

Sample: 19812016

Included observations: 33

$$
\text { Coefficient Uncentered Centered }
$$




\begin{tabular}{cccc} 
Variable & Variance & VIF & VIF \\
\hline \hline C & 0.004236 & 1.816468 & NA \\
D(LNUNEMP(-1)) & 0.036774 & 2.134072 & 2.108777 \\
D(LNUNEMP(-2)) & 0.025776 & 1.479169 & 1.454946 \\
D(LNEX(-1)) & 0.044034 & 2.318361 & 1.763720 \\
D(LNEX(-2)) & 0.048304 & 2.525635 & 1.937603 \\
D(LNINFL(-1)) & 0.005200 & 1.342768 & 1.342756 \\
D(LNINFL(-2)) & 0.004738 & 1.287106 & 1.285391 \\
D(LNINTRT(-1)) & 0.134173 & 2.868059 & 2.854975 \\
D(LNINTRT(-2)) & 0.096550 & 2.160367 & 2.139422 \\
D(LNPOP(-1)) & 141.2815 & 4.245635 & 4.234142 \\
D(LNPOP(-2)) & 90.26023 & 4.746861 & 4.731695 \\
ECM(-1) & 0.037799 & 2.691902 & 2.691498 \\
\hline \hline
\end{tabular}

From the Table 10 above, it can be seen that the Centered VIF for all the variables are less 10 (i.e VIF $<10$ ), this means that there is no presence of Multicollearity among the variables or in the model.

\section{Table 11: Serial Correlation LM Test}

Breusch-Godfrey Serial Correlation LM Test:

\begin{tabular}{llll}
\hline \hline F-statistic & 0.306562 & Prob. F(2,19) & 0.7395 \\
Obs*R-squared & 1.031610 & Prob. Chi-Square(2) & 0.5970 \\
\hline \hline
\end{tabular}

From Table 11 above, the test of serial correlation was carried out on the model, the P-value = $0.7395>0.05$ revealed that there is no serial correlation in the Error of the estimated ECM model. The implication of this also is that the fitted unemployment rate model is good for forecasting.

\section{Table 12: Heteroskedasticity Test}

Heteroskedasticity Test: Breusch-Pagan-Godfrey

\begin{tabular}{llll}
\hline \hline F-statistic & 3.131981 & Prob. F(11,21) & 0.0118 \\
Obs*R-squared & 20.50266 & Prob. Chi-Square(11) & 0.0389 \\
Scaled explained SS & 5.633895 & Prob. Chi-Square(11) & 0.8966 \\
\hline \hline
\end{tabular}

From table 12 above, the test of Heteroskedasticity test was carried out on the model, the result revealed that the variance of the residual are not constant, since the $(\mathrm{P}$-value $=0.0118<0.05)$. This implies that there is evidence of Heteroskedastic in the Residual. This could be as a result of the transformation of the variables. 


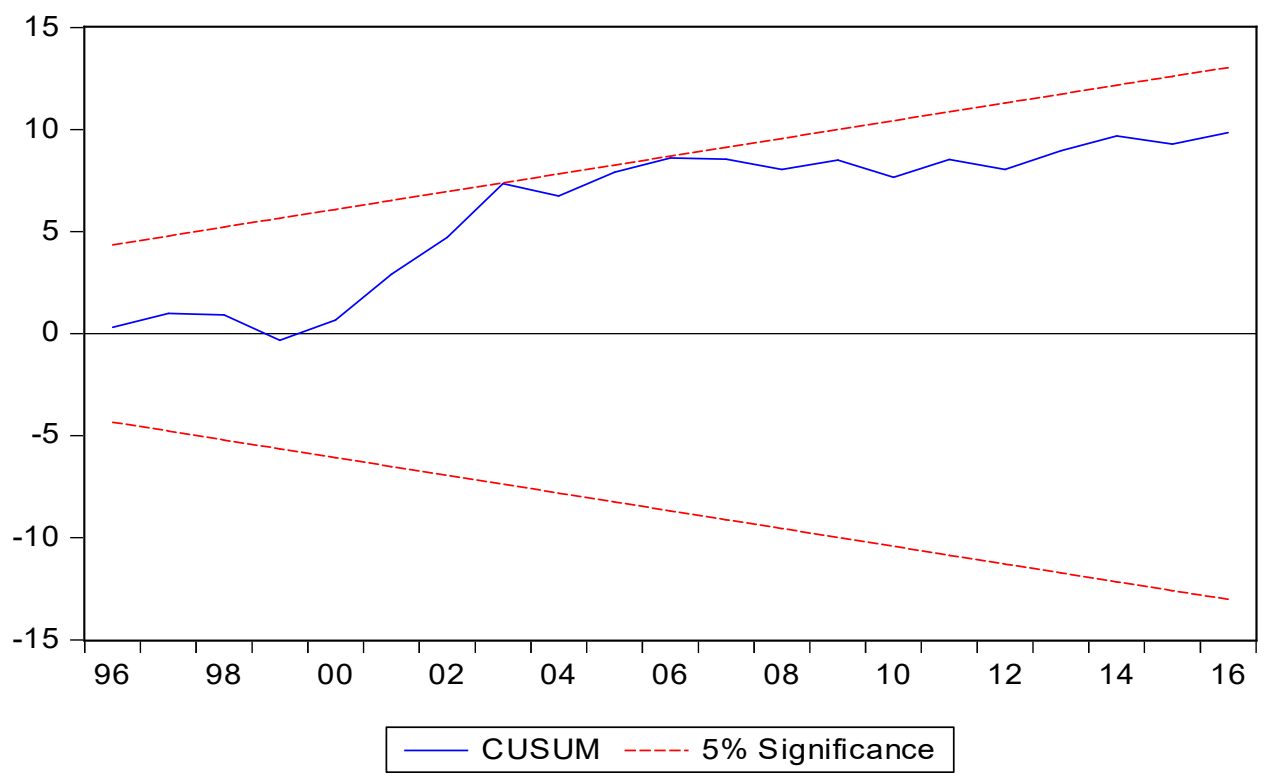

Fig. 4: Plot of CUSUM Test for Stability of ECM Model

Figure 4 above, the results indicated the absence of any instability of the coefficients because the plot of the CUSUM statistic falls inside the critical bands of the $5 \%$ confidence interval of parameter stability. In essence, we say the model is Stable because the blue line is strictly between the Red Line (at 5\% significance). This also further tells us that this model is good for forecasting.

\section{Table 13: Pairwise Granger Causality Tests}

Pairwise Granger Causality Tests

Date: 05/18/18 Time: 12:02

Sample: 19812016

Lags: 2

\begin{tabular}{|c|c|c|c|}
\hline Null Hypothesis: & Obs & F-Statistic & Prob. \\
\hline LNINFL does not Granger Cause LNEX & \multirow[t]{2}{*}{34} & 2.22268 & 0.1264 \\
\hline LNEX does not Granger Cause LNINFL & & 1.00963 & 0.3768 \\
\hline LNINTRT does not Granger Cause LNEX & \multirow[t]{2}{*}{34} & 0.08249 & 0.9210 \\
\hline LNEX does not Granger Cause LNINTRT & & 0.46355 & 0.6336 \\
\hline LNPOP does not Granger Cause LNEX & \multirow[t]{2}{*}{34} & 1.31113 & 0.2850 \\
\hline LNEX does not Granger Cause LNPOP & & 2.17474 & 0.1318 \\
\hline LNUNEMP does not Granger Cause LNEX & \multirow[t]{2}{*}{34} & 0.11264 & 0.8939 \\
\hline LNEX does not Granger Cause LNUNEMP & & 9.82263 & 0.0006 \\
\hline LNINTRT does not Granger Cause LNINFL & \multirow[t]{2}{*}{34} & 0.27479 & 0.7617 \\
\hline LNINFL does not Granger Cause LNINTRT & & 3.27355 & 0.0523 \\
\hline
\end{tabular}




\begin{tabular}{|c|c|c|c|}
\hline $\begin{array}{l}\text { LNPOP does not Granger Cause LNINFL } \\
\text { LNINFL does not Granger Cause LNPOP }\end{array}$ & 34 & $\begin{array}{l}2.79819 \\
0.59109\end{array}$ & $\begin{array}{l}0.0774 \\
0.5603\end{array}$ \\
\hline LNUNEMP does not Granger Cause LNINFL & \multirow[t]{2}{*}{34} & 2.96622 & 0.0673 \\
\hline LNINFL does not Granger Cause LNUNEMP & & 1.86380 & 0.1732 \\
\hline LNPOP does not Granger Cause LNINTRT & \multirow[t]{2}{*}{34} & 0.21096 & 0.8110 \\
\hline LNINTRT does not Granger Cause LNPOP & & 7.32613 & 0.0027 \\
\hline LNUNEMP does not Granger Cause LNINTRT & \multirow[t]{2}{*}{34} & 1.12379 & 0.3388 \\
\hline LNINTRT does not Granger Cause LNUNEMP & & 0.04886 & 0.9524 \\
\hline LNUNEMP does not Granger Cause LNPOP & \multirow[t]{2}{*}{34} & 3.33373 & 0.0498 \\
\hline LNPOP does not Granger Cause LNUNEMP & & 0.46011 & 0.6357 \\
\hline
\end{tabular}

From Table 13 above, it revealed that in the short run, Exchange rate causes Unemployment. This corresponds to the result obtained in the ECM model.

\subsection{Discussion of Findings}

The descriptive statistics revealed mean values for log of Exchange Rate, Log of Inflation rate, Log of Interest Rate, Log of Population Growth and Log of Unemployment are 3.293656, $2.674964,2.828446,0.947595$ and 2.103168 respectively. The descriptive statistics further revealed that the variables are normally distributed, this agrees with the work of Fuhrer (2017). The implication of this is that the FMOLS and ECM models are appropriate because these models assume normal distribution.

The Augmented Dickey Fuller test revealed that Exchange Rate, Inflation rate, Interest Rate, Population Growth and Unemployment are integrated at order 1 that is $\mathrm{I}(1)$, this is expected because most macro-economic variables have trends in them. This is in line with the work of Libanio (2005). Since the variables are integrated, one may suspect the possibility of cointegration which means Long run relationship. The Johansen cointegration test for the macro variables revealed that the variables are cointegrated which is in line with economic expectation that state that most macro-economic variables tends to exhibit long run relationship (Kwon and Shin, 1999). Since the variables are integrated of order one and also cointegrated, the FMOLS model was then applied to the variables using Unemployment rate as the dependent variables while others are independent variables. The estimated FMOLS revealed that the expected unemployment figure in Nigeria will be $-8.6 \%$ if there are no effects of these and other macro variables. The estimated FMOLS model also revealed that there is a positive relationship between Exchange rate and Unemployment Rate in Nigeria. By this relationship, it means that if 
there is unit increase in Exchange Rate, Unemployment Rate will Increase by 0.3 per unit increase in Exchange Rate in Nigeria. This contradicts the result of Bakhshi and Ebrahimi (2016) for Iran economy. The implication of our result shows that the Nigerian economy depends more on Importation. The FMOLS model also revealed a significant positive relationship between Population growth and unemployment rate in Nigeria that is if there is a unit increase in Population Growth, Unemployment Rate will increase by 14.49 per unit increase in Population Growth. The implication is that an uncontrolled population growth will lead to explosion on unemployment Rate, this is in line with the work of Loku and Deda (2013).

The FMOLS model also revealed that Interest Rate and Inflation Rate are negatively related to Unemployment but only Interest Rate is Significant $(\mathrm{P}$-value $=0.0124<0.05)$. This means that if there is unit increase in Inflation Rate, Unemployment Rate will decrease by 0.16 per unit increase in Inflation Rate. Also, if there is unit increase in Interest Rate, Unemployment Rate will decrease by 1.28 per unit increase in Interest Rate. This agrees with (Alisa 2015)., The Coefficient of determination (R-squared) shows that $74 \%$ variation in unemployment rate can be explained jointly by four independent variables such as log of Interest Rate, log of Exchange Rate, $\log$ of inflation rate and $\log$ of Population growth. The rest $26 \%$ variation in Unemployment Rate can be explained by residuals or other variables other than the four independent variables. The FMOLS model also revealed that the variables are cointegrated, no presence of Multicollinearity, the expected fitted values of the model are close to the actual while the Error from the model are normally distributed which fulfil the assumption of the OLS .

To understand the Short run Dynamics among these macro variables, the ECM model was adopted. The VAR selection criteria revealed that an optimum Lag of 2 was selected. The fitted ECM model revealed a Short Run impact from Exchange Rate to Unemployment Rate in Nigeria. This also implies that Nigerian economy depend on Importation. This agrees with the work of Nyahokwe \& Ncwadi (2013). While the ECM coefficient is -0.489 which has the expected sign and it is also significant, this means that for the system to come to equilibrium, it takes a speed up of $48.9 \%$ annually. This agrees with the work of Alisa (2015).

The diagnostic Test revealed that there are no presence of Multicollinearity, Serial correlation. Lastly, the expected ECM model is suitable for forecasting. 


\subsection{Conclusion and Recommendations}

This study investigated the Lon Run and the short Run relationship among all the macro variables (that is Unemployment, Inflation Rate, Exchange Rate and Interest Rate). A secondary data was sourced from CBN Statistical Bulletin and World Bank website. The descriptive statistics revealed mean values for log of Exchange Rate, Log of Inflation rate, Log of Interest Rate, Log of Population Growth and Log of Unemployment are 3.293656, 2.674964, 2.828446, 0.947595 and 2.103168 respectively. The descriptive statistics further revealed that the variables are normally distributed. The Augmented Dickey Fuller test revealed that Exchange Rate, Inflation rate, Interest Rate, Population Growth and Unemployment are integrated at order 1 that is $\mathrm{I}(1)$, this is expected because most macroeconomic variables have trends in them. The Johansen cointegration test for the macro variables revealed that the variables are cointegrated. Since the variables are integrated of order one and also cointegrated, the FMOLS model was then applied to the variables using Unemployment rate as the dependent variables while others are independent variables. The estimated FMOLS revealed that the expected unemployment figure in Nigeria will be $-8.6 \%$ if there are no effects of these and other macro variables. The estimated FMOLS model also revealed that there is a positive relationship between Exchange rate and Unemployment Rate in Nigeria. The FMOLS model also revealed a significant positive relationship between Population growth and unemployment rate in Nigeria that is if there is a unit increase in Population Growth, Unemployment Rate will increase by 14.49 per unit increase in Population Growth. The FMOLS model also revealed that Interest Rate and Inflation Rate are negatively related to Unemployment but only Interest Rate is Significant (P-value $=0.0124<$ 0.05). The Coefficient of determination (R-squared) shows that $74 \%$ variation in unemployment rate can be explained jointly by four independent variables such as log of Interest Rate, $\log$ of Exchange Rate, log of inflation rate and $\log$ of Population growth. The rest 26\% variation in Unemployment Rate can be explained by residuals or other variables other than the four independent variables.

The FMOLS model also revealed that the variables are cointegrated, no presence of Multicollinearity, the expected fitted values of the model are close to the actual while the Error from the model are normally distributed. 
To understand the Short run Dynamics among these macro variables, the ECM model was adopted. The VAR selection criteria revealed that an optimum Lag of 2 was selected. The fitted ECM model revealed a Short Run impact from Exchange Rate to Unemployment Rate in Nigeria. While the ECM coefficient is -0.489 which has the expected sign and it is also significant, this means that for the system to come to equilibrium, it takes a speed up of $48.9 \%$ annually. The diagnostic Test revealed that there are no presence of Multicollinearity, Serial correlation. The estimated ECM model is suitable for forecasting.

In summary, this study revealed that Exchange Rate and Population Growth are significant and are positively related to Unemployment rate while Inflation Rate and Interest Rate are negatively related to Unemployment in Nigeria with only Interest Rate being significant.

The following are recommended due to the findings of this study:

i. Government should create other sources of employment like sports activities that will adequately engage the youths.

ii. Also youth empowerment should be encouraged in order to encourage small and medium scale enterprises through the use of some low interest finance banks like BOI (Bank of Industry) for the grassroots. This is to encourage the Small and Medium enterprise for the youths with great insights.

iii. Government should endeavor to create new classes of loan with reduced interest rate which is targeted at financing young entrepreneurial and based on that it means that banks and other financial institutions still have a role to play.

iv. Improvement is required on other sector such as the non-oil sector of the economy like Agriculture

v. Control of the population may be necessary by Government.

vi. Skill acquisition and trainings should be introduced in a wise way so that it will engage the unemployed in order to reduce the unemployment situation in the country. 


\section{REFERENCES}

Adenomon, M. O.: Ahmed, I. \& Abubakar, M. A. (2018): Fully Modified Ordinary Least Squares Analysis of the Long Run Interrelationship Among Macroeconomic Variables in Nigeria. A Paper presented at the $2^{\text {nd }}$ FNAS National Conference, Nasarawa State University, Keffi, $27^{\text {th }}$ to $30^{\text {th }}$ May, 2018.

Afzal Muhammad \& Awais S. (2012): Inflation-Unemployment Trade Off: Evidence from Pakistan, Journal of Global Economy 8(1), 21-32.

Ajayi, A. and Mougoue, M. (1996). “On the Dynamic Relationship Between Stock Prices and Exchange Rates” Journal of Financial Research 9(2):193-207.

Alisa, M.(2015): The Relationship Between Inflation and Unemployment: A theoretical Discussion about the Phillips Curve. Journal of International Business and Economics, 3(2): 89-97.

Aminu U. \& Anono A. Z.(2012): An Empirical Analysis Of The Relationship Between Unemployment And Inflation In Nigeria From 1977-2009, Economics And Finance Review. 1(12): $42-61$.

Baah-Boateng,W. (2013): Determinants of Unemployment in Ghana. African Development Review. 25(4):85-399

Bakhshi, Z. \& Ebrahimi,M. (2016) : The Effect of Real Exchange rate on Unemployment Marketing and Branding Research,3:4-13.

Central Bank of Nigeria (2003): Contemporary Economic Policy Issues in Nigeria. Abuja.

Cheema A. R., \& Atta A. (2014): Economic Determinants Of Unemployment In Pakistan: CoIntegration Analysis, International Journal Of Business And Social Science 5(3):209-221

Countries: Evidences from Tanzania. Journal of Economics and Sustainable Development, 4(14): 2222 - 2855

Eita, J. H. \& Johanson M. A. (2010): Determinants of Unemployment in Namibia. International Journal of Business and Management. 5(10): 92 - 104.

El-Agrody, N. M., Othman, A. Z., \& Hassan, M. B.-D. (2010): Economic Study of Unemployment in Egypt and Impacts on GDP. Nature and Science, 8(10):102-111.

Engle, R. F. and Granger, C. W. J.(1987): Co-Integration and Error Correction: Representation, Estimation and Testing. Econometrica. 55(2):251-276.

Fuher, J.(2017): Expectations as a source of macroeconomic persistence: Evidence from survey expectation in a dynamic macro model. Journal of Monetary Economics 86: 22-35. 
Habte Z, Market Integration for Oxen Prices Using Vector Error Correction Model (VECM) in Ethiopia. Int. J. of Tech. Enhancement and Emerging Eng. Research 2:6-9(2014).

Hendry, D. F.(2003): J. Denis Sargan and the Origins of LSE Econometric Methodology. Econometric Theory, 19(3):457-480.

Johansen S \& Juselius K, Maximum Likelihood Estimation and Inference on Cointegration with Application to the Demand for Money. Oxford Bullentin of Econs \& Stat. 52:169 $-210(1990)$.

Kabaklarli, E., \& Bulus, A. (2011): Economic Determinants of Turkish Youth Unemployment Problem: Co-Integration Analysis. International Conference on Applied Economics. 267.

Kemi F. A. \& Dayo B. O. (2014): Unemployment and Economic Growth in Nigeria. Journal of Economics and Sustainable Development. 5(4): 138 - 144

Kuhe, D. A.(2016): An Econometric Analysis of Crime Determinants in Nigeria. Journal of the Nigerian Statistical Association, 28:1-15

Kwon, C.S and Shin, T.S (1999): Cointegration and causality between macro-economic Variables and stock Market Returns, Global Finance Journal, 10(1): 71-81.

Loku, A. \& Deda, G (2013): Unemployment in Relation of Growth Population. International Journal of Research in Social Sciences, 2(2):31-38.

Maigwa R. \& Kipesha E. F. (2013): Determinants of Youth Unemployment in Developing Countries: Evidences from Tanzania. Journal of Economics and Sustainable Development, 4(14): 2222 - 2855

Maqbool M. S, Sattar T., Mahmood A. \& Bhalli M. N. (2013): Determinant of Unemployment Empirical Evidences from Pakistan Economics and Social Review. 51(2):191-207

Muhdin, M.B. (2016): Determinants of youth unemployment of urban areas of Ethopia. International Journal of Scientific and Research Publications, 6(5): 43-350.

Nasir, F., Cheema, M. A., Zafar M.I., \& Batool, Z. (2009): Socio-Economic Impacts of Unemployment in Urban Faisalabad, Pakistan. Journal of social science, 18(3): 183-188

Nyahokwe,O. \& Ncwadi, R (2013): Import Of Exchange Rate Volatility on Unemployment in South Africa. Mediterranean Journal of Social Science, 4(3): 109-120.

Okun, A. (1962): 'Potential GNP: Its Measurement and Significance', in the 1962 Proceedings Of Business and Economic Statistics Section, American Statistical Association. 
Pallis, D. (2006): The Trade-off between inflation and unemployment in new European Union member states. International Research Journal of Finance and Economics 1:81-97.

Phillips, P. C. B. \& Hansen, B. E. (1990): Statistical Inference in Instrumental Regression with I(1) Processes. The Review of Economic Studies, 57(1): 99-125.

Phillips, P. C. B. \& Loretan, M.(1991): Estimating Long-Run Economic Equilibra. The Review of Economic Studies, 58(3): 407-436.

Salmon, M.(1982): Error Correction Mechanisms. Economic Journal 92, 615-629.

Salvatore, D. and Reagle, D. (2002): Schaum's Outline of Theory and Problems of Statistics and Econometrics (2 ed). New York: McGraw-Hill.

Sargan, J. D.(1964): Wages and Prices in the United Kingdom: A Study in Econometric Methodology (with discussion). In P. E. Hart, G. Mills \& J. K. Whitaker (eds), Econometric Analysis for national Economic Planning, Vol. 16 of Colston Papers, Pp. 25-63, London: Butterworth.

\section{Appendix}

Table 1: Annual Data on Exchange Rate, Inflation Rate, Interest Rate, Unemployment Rate and Population Growth from 1981 to 2016.

\begin{tabular}{|r|r|r|r|l|l|}
\hline \multicolumn{1}{|l|}{ Year } & \multicolumn{1}{l|l}{$\begin{array}{l}\text { Exchange } \\
\text { rate }\end{array}$} & $\begin{array}{l}\text { Inflation } \\
\text { rate }\end{array}$ & $\begin{array}{l}\text { Interest } \\
\text { Rate }\end{array}$ & $\begin{array}{l}\text { Unemployment } \\
\text { Rate }\end{array}$ & $\begin{array}{l}\text { Pop } \\
\text { Growth }\end{array}$ \\
\hline 1981 & 0.61 & 20.9999 & 7.75 & 6.4 & 2.71506 \\
\hline 1982 & 0.673 & 7.6 & 10.25 & 6.4 & 2.60268 \\
\hline 1983 & 0.724 & 23.1999 & 10 & 6.4 & 2.53541 \\
\hline 1984 & 0.765 & 39.6 & 12.5 & 6.2 & 2.52929 \\
\hline 1985 & 0.894 & 5.5 & 9.25 & 6.1 & 2.56273 \\
\hline 1986 & 2.021 & 5.4 & 10.5 & 5.3 & 2.6032 \\
\hline 1987 & 4.018 & 10.2 & 17.5 & 7 & 2.62564 \\
\hline 1988 & 4.537 & 56.1002 & 16.5 & 5.3 & 2.63093 \\
\hline 1989 & 7.392 & 50.4998 & 26.7999 & 4.5 & 2.61241 \\
\hline 1990 & 8.038 & 7.5 & 25.5 & 3.5 & 2.57904 \\
\hline 1991 & 9.909 & 12.9 & 20.01 & 3.1 & 2.54561 \\
\hline 1992 & 17.298 & 44.5998 & 29.8 & 3.4 & 2.52124 \\
\hline 1993 & 22.051 & 57.1998 & 18.3199 & 2.7 & 2.50297 \\
\hline 1994 & 21.886 & 56.9999 & 20.9999 & 2 & 2.493 \\
\hline 1995 & 21.886 & 72.9001 & 20.18 & 1.8 & 2.48943 \\
\hline 1996 & 21.886 & 30.3999 & 19.7401 & 3.4 & 2.48837 \\
\hline
\end{tabular}




\begin{tabular}{|r|r|r|r|r|r|}
\hline 1997 & 21.886 & 8.2 & 13.54 & 3.2 & 2.48818 \\
\hline 1998 & 21.886 & 10.3 & 18.2899 & 3.2 & 2.49072 \\
\hline 1999 & 92.694 & 6.7 & 21.3201 & 3 & 2.49581 \\
\hline 2000 & 102.105 & 6.9 & 17.98 & 18.1 & 2.5034 \\
\hline 2001 & 111.943 & 18.9 & 18.2899 & 13.7 & 2.51121 \\
\hline 2002 & 120.97 & 12.9 & 24.8501 & 12.2 & 2.52111 \\
\hline 2003 & 129.356 & 14 & 20.7101 & 14.8 & 2.53684 \\
\hline 2004 & 133.5 & 14.9 & 19.18 & 11.8 & 2.55924 \\
\hline 2005 & 132.146 & 17.9 & 17.95 & 11.9 & 2.58522 \\
\hline 2006 & 128.652 & 8.2 & 17.26 & 13.7 & 2.61039 \\
\hline 2007 & 125.834 & 5.3 & 16.94 & 14.6 & 2.63165 \\
\hline 2008 & 118.567 & 11.6001 & 16.94 & 14.9 & 2.64897 \\
\hline 2009 & 148.88 & 13.7001 & 15.14 & 19.7 & 2.66122 \\
\hline 2010 & 150.298 & 10.8 & 18.99 & 21.1 & 2.66875 \\
\hline 2011 & 153.861 & 10.3 & 17.59 & 23.9 & 2.67475 \\
\hline 2012 & 157.499 & 11.5 & 16.02 & 24.3 & 2.67766 \\
\hline 2013 & 157.312 & 8.5 & 17.0899 & 28.5 & 2.67292 \\
\hline 2014 & 158.553 & 8.05 & 16.28 & 30 & 2.65955 \\
\hline 2015 & 192.439 & 8.2 & 16.8599 & 24 & 2.64036 \\
\hline 2016 & 253.489 & 9.6 & 16.54 & 25 & 2.61903 \\
\hline
\end{tabular}

Source: CBN Statistical Bulletin (2016) \& World Bank Website (www.worldbank.org)

Table 2: Natural Log Transformation of the Annual Data on Exchange Rate, Inflation Rate, Interest Rate, Unemployment Rate and Population Growth from 1981 to 2016.

\begin{tabular}{|r|r|r|r|r|r|}
\hline \multicolumn{1}{|l|}{ year } & \multicolumn{1}{|l|}{ LNEX } & LNINFL & LNINTRT & LNPOP & LNUNEMP \\
\hline 1981 & -0.4943 & 3.04452 & 2.04769 & 0.998815 & 1.8563 \\
\hline 1982 & -0.39616 & 2.02815 & 2.32728 & 0.95654 & 1.8563 \\
\hline 1983 & -0.32283 & 3.14415 & 2.30259 & 0.930356 & 1.8563 \\
\hline 1984 & -0.26801 & 3.67883 & 2.52573 & 0.927938 & 1.82455 \\
\hline 1985 & -0.11227 & 1.70475 & 2.22462 & 0.941074 & 1.80829 \\
\hline 1986 & 0.70339 & 1.6864 & 2.35138 & 0.956742 & 1.66771 \\
\hline 1987 & 1.39076 & 2.32239 & 2.8622 & 0.965324 & 1.94591 \\
\hline 1988 & 1.5122 & 4.02714 & 2.80336 & 0.967338 & 1.66771 \\
\hline 1989 & 2.00034 & 3.92197 & 3.2884 & 0.960275 & 1.50408 \\
\hline 1990 & 2.08416 & 2.0149 & 3.23868 & 0.947416 & 1.25276 \\
\hline 1991 & 2.29349 & 2.55723 & 2.99623 & 0.934371 & 1.1314 \\
\hline 1992 & 2.85061 & 3.79773 & 3.39451 & 0.924751 & 1.22378 \\
\hline 1993 & 3.09336 & 4.04655 & 2.90799 & 0.917478 & 0.99325 \\
\hline 1994 & 3.08585 & 4.04305 & 3.04452 & 0.913485 & 0.69315 \\
\hline 1995 & 3.08585 & 4.28909 & 3.00469 & 0.912056 & 0.58779 \\
\hline 1996 & 3.08585 & 3.41444 & 2.98265 & 0.911626 & 1.22378 \\
\hline
\end{tabular}




\begin{tabular}{|r|r|r|r|r|r|}
\hline 1997 & 3.08585 & 2.10413 & 2.60565 & 0.911553 & 1.16315 \\
\hline 1998 & 3.08585 & 2.33214 & 2.90635 & 0.912574 & 1.16315 \\
\hline 1999 & 4.5293 & 1.90211 & 3.05965 & 0.914615 & 1.09861 \\
\hline 2000 & 4.626 & 1.93152 & 2.88926 & 0.917649 & 2.89591 \\
\hline 2001 & 4.71799 & 2.93916 & 2.90635 & 0.920766 & 2.6174 \\
\hline 2002 & 4.79554 & 2.55723 & 3.21286 & 0.924698 & 2.50144 \\
\hline 2003 & 4.86257 & 2.63906 & 3.03062 & 0.930919 & 2.69463 \\
\hline 2004 & 4.8941 & 2.70136 & 2.95387 & 0.93971 & 2.4681 \\
\hline 2005 & 4.88391 & 2.8848 & 2.88759 & 0.949811 & 2.47654 \\
\hline 2006 & 4.85711 & 2.10413 & 2.84839 & 0.9595 & 2.6174 \\
\hline 2007 & 4.83496 & 1.66771 & 2.82968 & 0.967613 & 2.68102 \\
\hline 2008 & 4.77548 & 2.45101 & 2.82968 & 0.97417 & 2.70136 \\
\hline 2009 & 5.00314 & 2.6174 & 2.71734 & 0.978785 & 2.98062 \\
\hline 2010 & 5.01262 & 2.37955 & 2.94391 & 0.981609 & 3.04927 \\
\hline 2011 & 5.03605 & 2.33214 & 2.86733 & 0.983858 & 3.17388 \\
\hline 2012 & 5.05942 & 2.44235 & 2.77384 & 0.984943 & 3.19048 \\
\hline 2013 & 5.05823 & 2.14007 & 2.83849 & 0.983171 & 3.3499 \\
\hline 2014 & 5.06609 & 2.08567 & 2.78994 & 0.978157 & 3.4012 \\
\hline 2015 & 5.25978 & 2.10413 & 2.82494 & 0.970914 & 3.17805 \\
\hline 2016 & 5.53532 & 2.26176 & 2.80578 & 0.962805 & 3.21888 \\
\hline
\end{tabular}

Table 14: Unit Root Test for Exchange Rate

Null Hypothesis: D(LNEX) has a unit root

Exogenous: Constant

Lag Length: 0 (Automatic - based on AIC, maxlag=9)

\begin{tabular}{lccc}
\hline \hline & t-Statistic & Prob.* \\
\hline \hline Augmented Dickey-Fuller test statistic & -5.020825 & 0.0002 \\
\hline Test critical values: & $1 \%$ level & -3.639407 & \\
& $5 \%$ level & -2.951125 & \\
& $10 \%$ level & -2.614300 & \\
\hline \hline
\end{tabular}

*MacKinnon (1996) one-sided p-values. 


\section{Table 15: Unit Root Test for Inflation Rate}

Null Hypothesis: D(LNINFL) has a unit root

Exogenous: Constant

Lag Length: 1 (Automatic - based on AIC, maxlag=9)

\begin{tabular}{lccc}
\hline \hline & t-Statistic & Prob.* \\
\hline \hline \multicolumn{2}{l}{ Augmented Dickey-Fuller test statistic } & -7.240855 & 0.0000 \\
\hline Test critical values: & 1\% level & -3.646342 & \\
& 5\% level & -2.954021 & \\
& $10 \%$ level & -2.615817 & \\
\hline \hline
\end{tabular}

*MacKinnon (1996) one-sided p-values.

\section{Table 16: Unit Root Test for Interest Rate}

Null Hypothesis: D(LNINTRT) has a unit root

Exogenous: Constant

Lag Length: 0 (Automatic - based on AIC, maxlag=3)

\begin{tabular}{lccc}
\hline \hline & t-Statistic & Prob. ${ }^{*}$ \\
\hline \hline Augmented Dickey-Fuller test statistic & -8.707736 & 0.0000 \\
\hline Test critical values: & $1 \%$ level & -3.639407 & \\
& $5 \%$ level & -2.951125 & \\
& $10 \%$ level & -2.614300 & \\
\hline \hline
\end{tabular}

*MacKinnon (1996) one-sided p-values.

\section{Table 17: Unit Root Test for Population Growth Rate}

Null Hypothesis: D(LNPOP) has a unit root

Exogenous: Constant

Lag Length: 1 (Automatic - based on AIC, maxlag=5)

\begin{tabular}{lccc}
\hline \hline & t-Statistic & Prob. $^{*}$ \\
\hline \hline Augmented Dickey-Fuller test statistic & -7.056791 & 0.0000 \\
\hline Test critical values: & $1 \%$ level & -3.646342 & \\
& $5 \%$ level & -2.954021 & \\
$10 \%$ level & -2.615817 & \\
\hline \hline
\end{tabular}

*MacKinnon (1996) one-sided p-values. 


\section{Table 18: Unit Root Test for Unemployment Rate}

Null Hypothesis: D(LNUNEMP) has a unit root

Exogenous: Constant

Lag Length: 0 (Automatic - based on AIC, maxlag=9)

\begin{tabular}{|c|c|c|c|}
\hline & & t-Statistic & Prob.* \\
\hline \multicolumn{2}{|c|}{ Augmented Dickey-Fuller test statistic } & -6.641959 & 0.0000 \\
\hline \multirow[t]{3}{*}{ Test critical values: } & $1 \%$ level & -3.639407 & \\
\hline & $5 \%$ level & -2.951125 & \\
\hline & $10 \%$ level & -2.614300 & \\
\hline
\end{tabular}

*MacKinnon (1996) one-sided p-values. 